Report No.

ER-B-96-02
U.S. Department of Fnergy

Office of Inspector General

Report on

Audit of Groundwater

Remediation Plans at the

Savannah River Site

\title{
MASTER
}

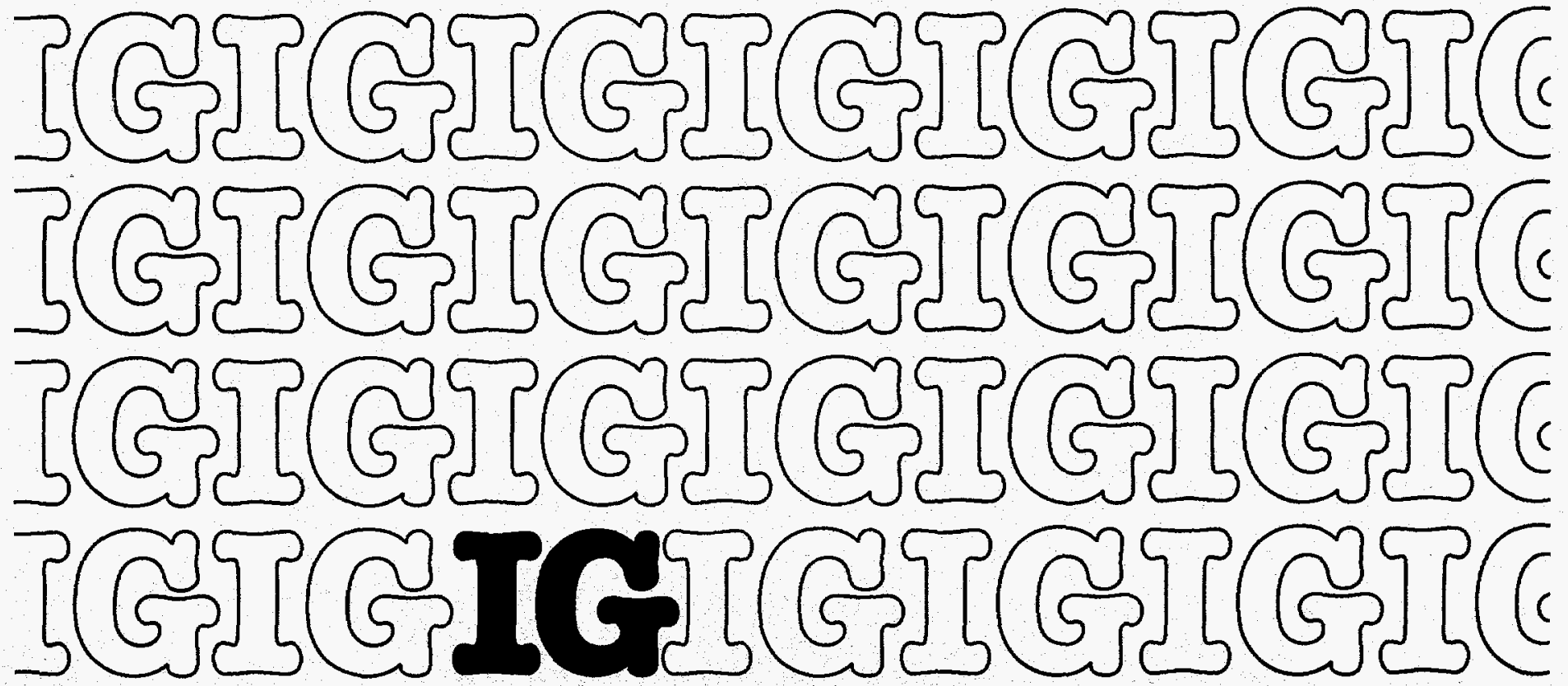


The office of Inspector General wants to make the distribution of its reports as customer friendly and cost effective as possible. Therefore, this report will be available electronically through the Internet five to seven days after publication at the following alternative addresses:

$$
\begin{aligned}
& \text { Department of Energy Headquarters Gopher } \\
& \text { gopher.hr.doe.gov } \\
& \text { Department of Energy Headquarters Anonymous FTP } \\
& \text { vml.hqadmin.doe.gov } \\
& \text { Department of Energy Human Resources and Administration } \\
& \text { Home Page } \\
& \text { http://ww.hr.doe.gov/refshelf.html }
\end{aligned}
$$

Your comments would be appreciated and can be provided on the Customer Response Form attached to the report.

This report can be obtained from the

$$
\text { U.S. Department of Energy }
$$

Office of Scientific and Technical Information

$$
\text { P.0. Box } 62
$$

Oak Ridge, Tennessee 37831 
U.S. DEPARTMENT OF ENERGY

OFFICE OF INSPECTOR GENERAL

\section{AUDIT OF}

\section{GROUNDWATER REMEDIATION PLANS}

AT THE SAVANNAH RIVER SITE

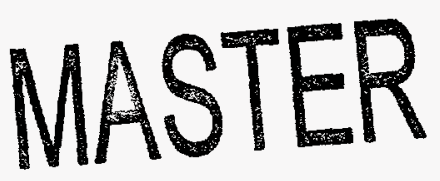

Report Number: ER-B-96-02

Eastern Regional Audit Office

Date of Issue: June 11, 1996

Oak Ridge, TN 37830

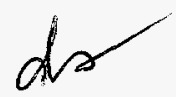



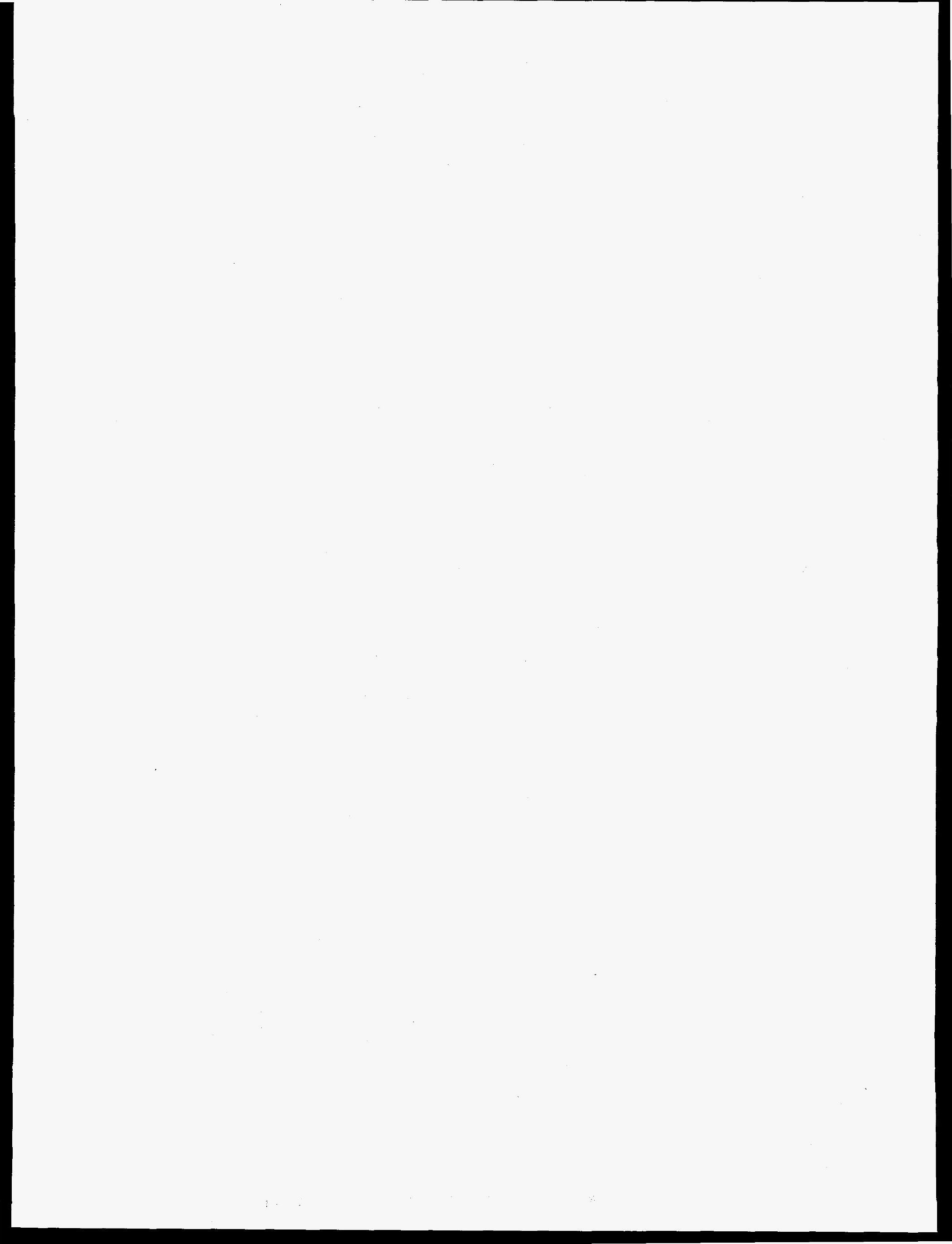


\section{DISCLAIMER}

Portions of this document may be illegible in electronic image products. Images are produced from the best available original document. 


\section{GROUNDWATER REMEDIATION PLANS}

AT THE SAVANNAH RIVER SITE

\section{TABLE OF CONTENTS}

\section{Page}

SUMMARY $\ldots \ldots \ldots \ldots \ldots \ldots \ldots \ldots \ldots \ldots \ldots \ldots \ldots \ldots \ldots \ldots \ldots$

PART $1 \quad-$ APPROACH AND OVERVIEW $\ldots \ldots \ldots \ldots \ldots \ldots \ldots \ldots \ldots$

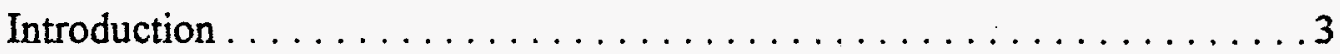

Scope and Methodology ........................ 3

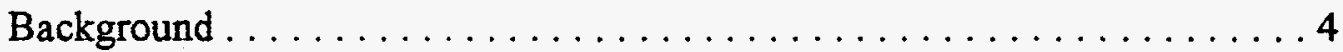

PART II - FINDINGS AND RECOMMENDATIONS $\ldots \ldots \ldots \ldots \ldots \ldots$

Groundwater Remediation Plans at the Savannah River Site $\ldots \ldots \ldots \ldots 6$

Part III - MANAGEMENT AND AUDITOR COMMENTS . . . . . . . . . . . . . 10 


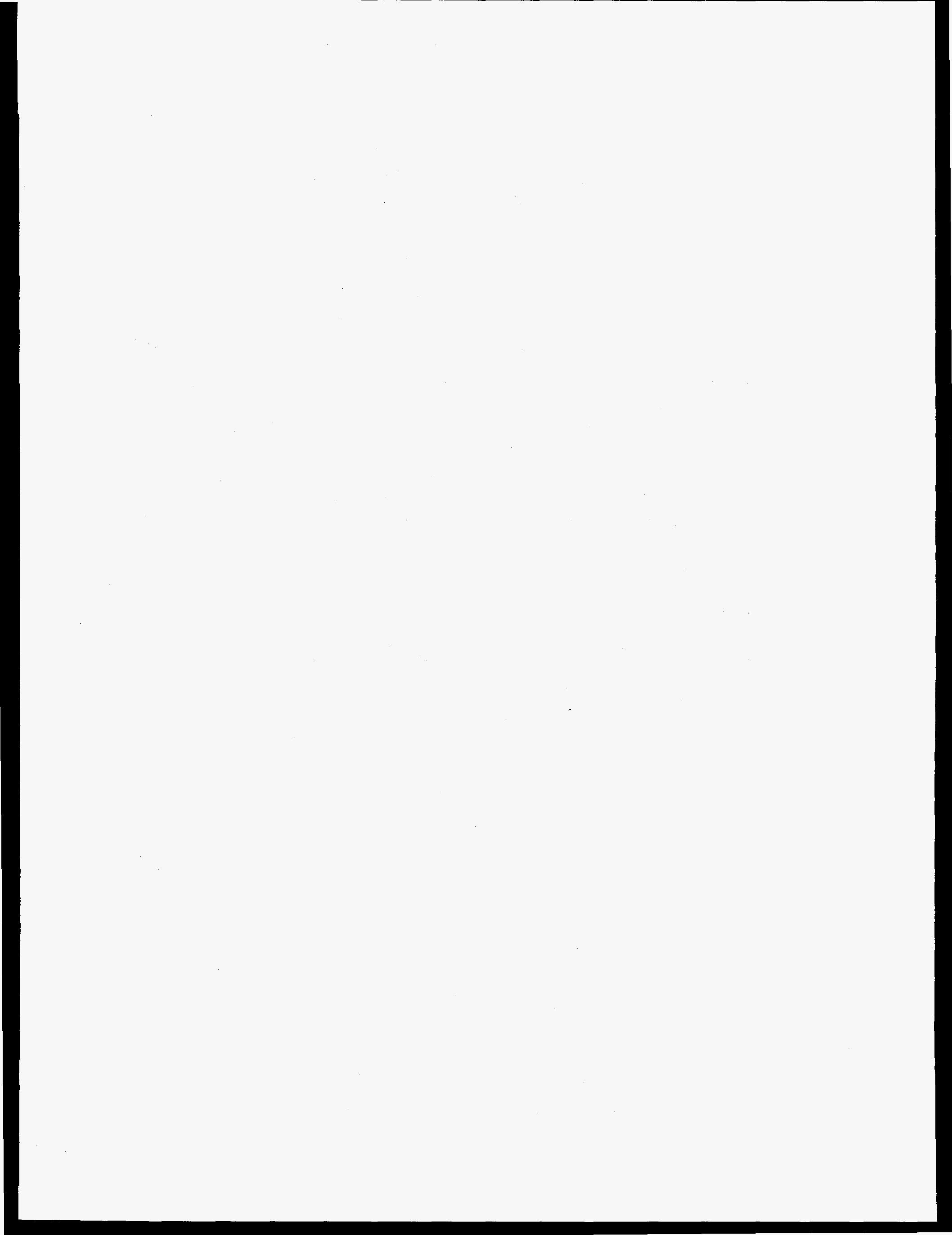

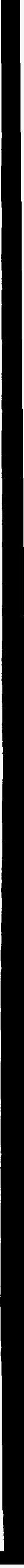




\title{
U.S. DEPARTMENT OF ENERGY \\ OFFICE OF INSPECTOR GENERAL \\ OFFICE OF AUDIT SERVICES
}

\author{
AUDIT OF \\ GROUNDWATER REMEDIATION PLANS \\ AT THE SAVANNAH RIVER SITE
}

Audit Report Number: ER-B-96-02

June 11, 1996

\section{$\underline{\text { SUMMARY }}$}

The Department of Energy was required to reduce groundwater contamination that represented a risk to human health or the environment. To achieve this goal, the Savannah River Operations Office (Savannah River) entered into several formal agreements with Federal and State regulators. The agreements described how Savannah River would reduce the level of contamination until the risks to human health and the environment were lowered to an acceptable level.

The agreements called for decreasing groundwater contamination to levels that would comply with South Carolina groundwater regulations, which would allow a hypothetical future resident to someday live above the $\mathrm{F}$ and $\mathrm{H}$ Areas and drink the groundwater. We believe basing the agreements on drinking water standards was unreasonable because no one will likely live above these areas or drink the groundwater. The more stringent drinking water standards were included in the planning process because Savannah River had not developed a Land Use Plan that would permit rational decision making for the entire site. Lacking a Land Use Plan, the environmental regulators assumed, and Savannah River acceded to, the most stringent usage scenario, that the groundwater under the $\mathrm{F}$ and $\mathrm{H}$ Areas might one day be used as a source of drinking water. It will take more than one hundred years for the subterranean groundwater to become safe enough for drinking water purposes.

Consequently, Savannah River may continue to pursue expensive remediation projects for longer than would be necessary to protect human health and the environment. However, the cost impact of unnecessary clean-up activities is indeterminable because acceptable contamination limits would still have to be negotiated with the South Carolina Department of Health and Environmental Control. 
We recommended that the Manager, Savannah River complete the development of a Land Use Plan for the Savannah River Site. We also recommended that, if the groundwater under the $\mathrm{F}$ and $\mathrm{H}$ Areas qualifies for reclassification, including the intended uses as described in the Land Use Plan, Savannah River should petition the South Carolina Department of Health and Environmental Control (SCDHEC) to reclassify the groundwater under the $\mathrm{F}$ and $\mathrm{H}$ Areas to Class GC as outlined in South Carolina's "Water Classifications and Standards."

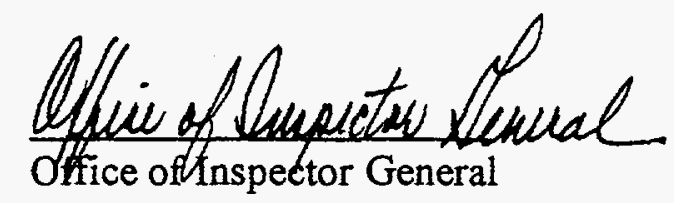




\section{$\underline{\text { PART I }}$}

\section{APPROACH AND OVERVIEW}

\section{INTRODUCTION}

The Savannah River Site's (Site) primary mission is to manage the waste products generated during the era of weapons production, and restore the environment to a level acceptable under current laws and regulations. The objective of the audit was to determine if the remediation project, intended to clean up the groundwater contamination under the $F$ and $H$ Areas, was designed to minimize cost while still protecting human health and the environment.

\section{SCOPE AND METHODOLOGY}

The audit was performed at the Site from August 13, 1994, through July 7, 1995. To accomplish the audit objective, we:

- reviewed applicable Federal, State, and Departmental regulations regarding groundwater remediation;

- reviewed current and proposed budget information concerning the groundwater remediation projects;

- interviewed the Savannah River Operations Office (Savannah River) and Westinghouse Savannah River Company (Westinghouse) project managers assigned to the groundwater remediation projects; and

- reviewed documentation pertaining to the history and the development of the groundwater remediation projects.

The audit was conducted in accordance with generally accepted Government auditing standards for performance audits, and included tests of internal controls and compliance with laws and regulations to the extent necessary to satisfy the objective of the audit. Because our review was limited, it would not necessarily have disclosed all internal control deficiencies that may have existed at the time of our audit. We placed no reliance on computer-generated data during this audit and, thus, did not test the reliability of any computer generated data.

We held an exit conference with the Chief Financial Officer, Savannah River, and staff on May 14,1996, to discuss the finding and recommendations presented in this report. Management's comments on the report are contained in Part III. 


\section{BACKGROUND}

The Site, located near Aiken, South Carolina, is owned by the Department of Energy (Department) and is managed and operated by Westinghouse. For over 40 years, the Site used five nuclear reactors to fulfill its primary mission of producing tritium and other radioisotopes for use in defense-related activities. In August 1988, the Department shut down the last of the Site's three operating reactors, and does not anticipate restarting any of these reactors. Subsequently, the Site's primary mission was changed from producing nuclear materials to managing the waste products generated during the era of weapons production, and restoring the environment to a level acceptable under current laws and regulations.

The two predominant laws that determined the acceptability of environmental conditions at the Site were the Resource Conservation and Recovery Act (RCRA) and the Comprehensive Environmental Response, Compensation and Liability Act (CERCLA). These laws were administered by both Federal and State regulators. The Federal regulator was the Environmental Protection Agency. The State regulator was the South Carolina Department of Health and Environmental Control (SCDHEC). SCDHEC had primary responsibility for overseeing environmental remediation actions required by RCRA.

To carry out its responsibilities for overseeing environmental remediation of groundwater, SCDHEC classified groundwater according to guidelines contained in the South Carolina "Water Classifications and Standards (Regulation 61 - 68)," dated May 28,1993. It was the policy of SCDHEC to maintain the quality of groundwater consistent with the highest potential use. SCDHEC has three classifications for groundwater: Classes GA, GB, and GC. Class GA was established for exceptionally valuable groundwater. Class GB was established for all groundwaters of the State which meet the definition of underground sources of drinking water. For Class GB groundwater, maximum levels for each regulated contaminant were set forth in the State Primary Drinking Water Regulations. SCDHEC realized that some groundwaters were not considered potential sources of drinking water, and would be of limited beneficial use. These groundwaters were classified GC.

Two sites contaminated prior to 1988 were the $F$ and $H$ Areas. From 1955 until 1988, waste water containing metals, nitrates, and radionuclides (primarily tritium), generated in the Site's chemical separations facilities, were discharged to three unlined earthen basins in the $F$ Area and four similar basins in the H Area. Some of the contaminants in these basins seeped into the groundwater. In 1986, Savannah River determined that the F and H Area seepage basins would be regulated under RCRA as mixed waste disposal facilities. SCDHEC approved closure activities for the $\mathrm{F}$ and $\mathrm{H}$ Area seepage basins in 1989. Closure activities consisted of stabilizing the sediment in the basins, backfilling the basins with clean soil, and installing an engineered, multilayer clay/soil cap over each basin. These closure activities, completed in 1991, have reduced the rate at which contaminants enter the aquifers below the basins by 95 percent. Even so, the groundwater that was reaching the surface had contaminant levels that exceeded acceptable levels uncier the South Carolina Pollution Control Act and, therefore, posed a risk to human health as well as the environment. 
To determine the degree of risks to human health and the environment, Savannah River had Westinghouse perform standardized computations and analyses. Samples of groundwater were collected from wells whose locations were chosen to provide a thorough coverage of the two areas. The samples were analyzed to detect contamination that might affect human health or non-human life forms in the environment. The degree of adverse effects was calculated following standard procedures. These procedures involved assumptions about possible exposure scenarios and about the ways that such exposure could occur. Common exposure scenarios were for: an employee on the Site in the normal course of business (On-Site Worker scenario); a human passing through the site (Trespasser scenario); a resident living just outside the Site (OffSite Resident scenario); a resident living above and drinking the contaminated groundwater (OnSite Resident scenario); and non-human life forms on and off the Site. Each of these scenarios was evaluated for the likelihood that it could occur.

Savannah River has been working with Federal and State regulators to improve environmental conditions at the Site. For example, Savannah River is initiating the first phase of the project to remediate the groundwater under the $\mathrm{F}$ and $\mathrm{H}$ Areas, in accordance with the RCRA Operating Permit (RCRA Agreement). The first phase, scheduled to last 5 years, will begin removing contaminants from the groundwater and will provide information about the groundwater that will be useful in refocusing the project during phases two and three. The operating costs, following initial construction, will be about $\$ 4.3$ million per year. 


\section{$\underline{\text { PART II }}$}

\section{FINDING AND RECOMMENDATIONS}

\section{Groundwater Remediation Plans at the Savannah River Site}

The Department of Energy (Department) was required to reduce groundwater contamination that represented a risk to human health or the environment. To achieve this goal, the Savannah River Operations Office (Savannah River) entered into several formal agreements with Federal and State regulators. The agreements described how Savannah River would reduce the level of contamination until the risks to human health and the environment were lowered to an acceptable level. We found that the agreements, covering the contamination in the groundwater under the $\mathrm{F}$ and $\mathrm{H}$ Areas, would allow Savannah River to pursue groundwater remediation projects that were necessary to protect human health and the environment. However, the agreements called for decreasing the groundwater contamination to levels that would meet the State's groundwater classification of GB, which would allow a hypothetical future resident to someday live above the $\mathrm{F}$ and $\mathrm{H}$ Areas and drink the groundwater. Basing the agreements on drinking water standards was unreasonable because no one will likely live above these areas or drink the groundwater. Drinking water standards were included in the planning process because Savannah River had not developed a Land Use Plan that would permit rational decision making for the entire site. Lacking a Land Use Plan, the environmental regulators assumed, and Savannah River acceded to, the most stringent usage scenario, that the groundwater might one day be used for drinking water purposes. Consequently, Savannah River may continue to pursue expensive remediation projects for longer than would be necessary to protect human health and the environment under less stringent scenarios. However, the cost impact of unnecessary clean-up activities is indeterminable because acceptable contamination limits would still have to be negotiated with the South Carolina Department of Health and Environmental Control.

\section{RECOMMENDATIONS}

We recommend that the Manager, Savannah River:

1. Complete the development of a Land Use Plan for the Savannah River Site (Site).

2. If the uses for the groundwater under the $F$ and $H$ Areas, as shown in the completed Land Use Plan, and other factors specified in South Carolina's "Water Classification and Standards," show that the groundwater under the $\mathrm{F}$ and $\mathrm{H}$ Areas qualifies for reclassification, petition the South Carolina Department of Health and Environmental Control (SCDHEC) to have those waters reclassified to Class GC. 


\section{MANAGEMENT REACTION}

Management concurred with both recommendations, but disagreed with our presentation of some material. Part III of this report discusses management's comments on our finding and recommendations.

\section{DETAILS OF FINDING}

\section{RESPONSIBILITY FOR PROTECTING HUMAN HEALTH AND THE ENVIRONMENT}

The Department was responsible for planning and executing effective environmental remediation projects needed to reduce the risk to human health and the environment. This responsibility extended to Savannah River's remediation projects for groundwater under the F and $\mathrm{H}$ Areas. The remedial actions required for the groundwater under the two areas were contained in the Resource Conservation and Recovery Act (RCRA) Agreement and the Federal Facilities Agreement, which were signed by Savannah River, Environmental Protection Agency (EPA), and SCDHEC. The RCRA Agreement incorporated the standards set by South Carolina's "Water Classifications and Standards (Regulation 61-68)" for Class GB groundwater. Groundwater that meets Class GB standards is clean enough to be a source of drinking water. While carrying out remediation projects that comply with the letter of environmental laws and regulations, the Department must also ensure that its legally correct actions do not leave an unacceptable risk to life forms on and around the Site.

\section{MAKING THE GROUNDWATER SAFE ENOUGH FOR HYPOTHETICAL FUTURE RESIDENTS}

The agreements, covering the contamination in the groundwater under the $\mathrm{F}$ and $\mathrm{H}$ Areas, would allow Savannah River to pursue groundwater remediation projects that were necessary to protect human health and the environment. Risk assessments and comparisons to standards set by South Carolina's "Water Classifications and Standards" showed that the remediation projects were necessary. The risk assessments showed that there would be an unacceptable carcinogenic risk to On-Site Workers and to On-Site Residents. Also, there was an unacceptable non-carcinogenic risk and radiological risk to On-Site Residents. The level of tritium that an On-Site Resident might consume from a domestic well in the $\mathrm{F}$ or $\mathrm{H}$ Areas was over 750 times the allowable level for drinking water ( 20 picocuries per milliliter) set by South Carolina's "Water Classifications and Standards." The level of tritium reaching the Four Mile Branch creek, from the $\mathrm{F}$ and $\mathrm{H}$ Areas, was 50 times the allowable level of 20 picocuries per milliliter. The concentration of mercury in the groundwater also exceeded acceptable levels in the $\mathrm{H}$ Areas. 
For the $\mathrm{F}$ and $\mathrm{H}$ Areas, the goal specified in the RCRA Agreement was to treat until the contaminant levels in extracted groundwater were less than those specified by South Carolina law. These levels mirrored the standards for primary drinking water. For example, the maximum acceptable tritium concentration was 20 picocuries per milliliter. In addition, the RCRA Agreement required Savannah River to use the Pump and Treat method of remediation, with reinjection. The Pump and Treat method entails pumping the contaminated groundwater to the surface, treating the groundwater by removing or stabilizing the contaminants, and then disposing of the cleansed groundwater by pumping it back underground or discharging it to the surface. In this case, all cleaned groundwater was to be reinjected into the ground. A properly designed Pump and Treat system will reduce the concentration of dissolved or suspended materials, such as metals, organic chemicals, and some radionuclides. However, the Pump and Treat method will not remove tritium from the groundwater under the $\mathrm{F}$ and $\mathrm{H}$ Areas.

The agreements called for decreasing groundwater contamination to levels that are more stringent than necessary to protect life forms, given the more likely current and future use of the $\mathrm{F}$ and $\mathrm{H}$ Areas. Specifically, the plan set a goal of decreasing the tritium and other contaminants under the $\mathrm{F}$ and $\mathrm{H}$ Areas' seepage basins to levels that would allow a hypothetical future resident to someday live above one of the areas, eat food grown in the contaminated area, and drink the groundwater. Basing the agreements on drinking water standards was unreasonable because, based on likely future use, no one will live above these areas or drink the groundwater.

\section{LAND USE PLAN}

Savannah River did not have a Land Use Plan showing the intended future uses of the Site's land and groundwater. Savannah River should have developed a Land Use Plan officially designating which parts of the 310 square mile Site could be used for different types of future activity. For example, the plan would have mapped out areas at the Site which: (1) could be institutionalized, never used, and be subject to controlled access; (2) could be used for industrial purposes, after adhering to moderate contamination standards; or (3) could be used for residential purposes, after adhering to the most stringent contamination standards. This lack of formal planning included the $\mathrm{F}$ and $\mathrm{H}$ Areas. Even though Savannah River officials stated that it was not their intention to use the $F$ and $\mathrm{H}$ Areas for residential purposes they had never committed that intention to writing. Therefore, Savannah River could not demonstrate that it was unlikely that the groundwater under the $\mathrm{F}$ and $\mathrm{H}$ Areas would ever be used as a source of drinking water.

Without a Land Use Plan outlining Savannah River's intended future use of the Site, the EPA and SCDHEC chose a conservative course of action by classifying the groundwater under the $\mathrm{F}$ and $\mathrm{H}$ Areas as Class GB, based on the assumption that the groundwater might be used for drinking water purposes at some time in the future. According to South Carolina law, all groundwater in the state of South Carolina is classified as GB by default. All GB groundwater must be brought into compliance with maximum concentration limits for the contaminants listed in the law. The maximum concentration limits are specific for each listed contaminant (such as 20 picocuries per milliliter for Tritium) and are applied to all GB groundwater in the state. 
Meeting these maximum concentration limits would make the groundwater clean enough to be used as drinking water.

The classification of the groundwater under the $F$ and $H$ Areas may be changed to $G C$ if the requirements of South Carolina law are met. GC groundwater is defined as groundwater not considered a potential source of drinking water, of limited beneficial use, and contaminated beyond levels that allow cleanup using methods reasonably employed in public water system treatment. Also, the groundwater must not migrate to GA or GB groundwater or discharge to surface water that could cause degradation. If the classification of the groundwater can be changed to class GC, the maximum concentration limits become negotiable. Until the maximum concentration limits are negotiable, it is unlikely that SCDHEC will change those limits.

One key prerequisite to reclassifying groundwater as GC is a demonstration that the groundwater will not have a potential use as drinking water. A statement to that effect, and the basis for that statement, could be included in a Land Use Plan, if Savannah River had one. Until Savannah River completes its Land Use Plan, specifying that the groundwater under the F and $\mathrm{H}$ A.reas will not be used for drinking water, there is no basis for SCDHEC to change the classification to GC. During this review, Savannah River took the first step in developing a Land Use Plan. In January 1996, Savannah River issued the "Savannah River Site Future Use Froject Report: Stakeholder-Preferred Recommendations for SRS Land and Facilities." As słated by management, "this project report is a prerequisite to developing a Land Use Plan and decision."

\section{EFFECT OF CLEANING TO DRINKING WATER STANDARDS}

Savannah River may continue to pursue expensive remediation projects for longer than would be necessary to protect human health and the environment from tritium, other radionuclides, and non-radioactive contaminants. Because of the presence of radionuclides, especially tritium, the isolated, subterranean groundwater will not be sufficiently decontaminated to drinking water standards for at least 100 years -- regardless of the treatment efforts. The water reaching the surface at the seepline is less contaminated due to dilution by rainwater and the natural retardation of contaminant migration. It should take less time for it to reach drinking water standards -- regardless of the treatment efforts. How much less time is indeterminable because Savannah River could not provide an estimate of how long it would take for the groundwater under the $\mathrm{F}$ and $\mathrm{H}$ Areas, reaching the surface at the seepline, to reach regulatory standards -- with or without treatment. Savannah River is currently calculating an estimate of clean-up times for treatment and non-treatment scenarios through computer modeling. 


\section{PART III}

\section{MANAGEMENT AND AUDITOR COMMENTS}

In responding to the initial draft version of this report, the Savannah River Operations Office (Savannah River) stated that they concurred with both recommendations, but disagreed with our presentation of some material.. A summary of management's comments and our replies follows.

Recommendation 1. Complete the development of a Land Use Plan for the Site.

Management Comments. Concur. Management agreed it should continue as planned with its development of a land use plan for the Site. This plan should be completed in approximately 2 years.

Management pointed out that the groundwater is classified as Class GB which is required by the South Carolina Pollution Control Act to be cleaned to drinking water standards. Although future Site use and risk are considered in remedial action decisions, a Land Use Plan would not provide shelter from adherence to that state law.

Auditor Comments. Management's proposed actions are responsive to the recommendation. The report does not suggest that Savannah River should not adhere to state law. In fact, compliance with the prerequisites specified in the law (including determining the highest future use of the groundwater) is what completion of the first recommendation will accomplish.

Recommendation 2. If the uses for the groundwater under the $F$ and $H$ Areas, as shown in the completed Land Use Plan, and other factors specified in South Carolina's "Water Classification and Standards", show that the groundwater under the $\mathrm{F}$ and $\mathrm{H}$ Areas qualifies for reclassification, petition the South Carolina Department of Health and Environmental Control (SCDHEC) to have those waters reclassified to Class GC.

Management Comments. Concur. Management stated that, if the groundwater appears to qualify for reclassification, Savannah River will petition SCDHEC to have the groundwater reclassified to Class GC.

Management pointed out that a RCRA Alternate Concentration Limit / Mixing Zone (ACL/MZ) demonstration must be conducted and approved by South Carolina to raise clean-up standards contained in the RCRA permit. A deviation from South Carolina law is not required to perform an ACL $/ M Z$ demonstration. The ACL/MZ process does not require reclassification of either the groundwater or the surface water bodies to be successful, but it must be part of a remedial action. Reclassification of the groundwater does not guarantee negotiation of maximum concentration limits. 
Management also pointed out three potential obstacles that must be cleared before reclassification is possible. Contaminated groundwater from the $\mathrm{F}$ and $\mathrm{H}$ Seepage Basins is presently discharging to a surface water body, Four Mile Branch, and causing degradation of that stream not allowed by the South Carolina Pollution Control Act. Secondly, groundwater contaminated by the $\mathrm{F}$ and $\mathrm{H}$ Seepage Basins is migrating laterally and downward in this area and may impact other aquifers not presently contaminated. Finally, Management stated that SCDHEC does not support aquifer reclassification.

Auditor Comments. Management's proposed actions are responsive to the recommendation. We continue to believe that Savannah River's proposed method of attempting to raise the acceptable level of contamination in the groundwater under the $\mathrm{F}$ and $\mathrm{H}$ Areas, by performing an $\mathrm{ACL} / \mathrm{MZ}$ demonstration, is unlikely to succeed for two reasons. First, Savannah River has already tried to achieve relaxed concentration limits using this method and been rejected twice in the past. In August 1995, PRC Environmental Management, Inc. reported to Savannah River that "Although relief from the concentration limits possibly may be obtained through a mixing zone request, denial of such a request is quite likely." Second, as long as the groundwater remains classified as Class GB, the maximum concentration limits are set out, in specific detail for each regulated contaminant, in South Carolina law. The law describes the procedures for removing a potential use (such as for drinking water) and the subsequent need to petition for reclassification. Since the law does not prescribe any specific maximum concentration limits for Class GC groundwater, they must be established for each body of groundwater. We agree that negotiations are not guaranteed in the law, but there is no reason to assume that SCDHEC would act arbitrarily or dictatorially and refuse to discuss (negotiate) the limits that would have to be established.

We agree that there are potential obstacles to reclassification of the groundwater under the $F$ and $\mathrm{H}$ Areas. First, our report does not suggest that Savannah River should attempt to curtail the treatment of the groundwater until the water reaching the surface at the seepline (and flowing into Four Mile Branch) meets the requirements for that area of surface water. We encourage Savannah River to continue pursuing responsible attempts to modify the standards that apply to Four Mile Branch and surrounding areas, such as the ACL/MZ demonstration. Second, there is always the possibility that one body of groundwater may contaminate another body of groundwater. If Savannah River obtains evidence that that is the case with the groundwater under the $\mathrm{F}$ and $\mathrm{H}$ Areas, reclassification may require treating both bodies of groundwater as one. Finally, we have no evidence that SCDHEC would not carefully consider any properly prepared and supported petition for reclassification of groundwater. 


\title{
CUSTOMER RESPONSE FORM
}

The Office of Inspector General has a continuing interest in improving the usefulness of its products. We wish to make our reports as responsive as possible to our customers' requirements, and therefore ask that you consider sharing your thoughts with us. On the back of this form, you may suggest improvements to enhance the effectiveness of future reports. Please include answers to the following questions if they are applicable to you:

1. What additional background information about the selection, scheduling, scope, or procedures of the audit or inspection would have been helpful to the reader in understanding this report?

2. What additional information related to findings and recommendations could have been included in this report to assist management in implementing corrective actions?

3. What format, stylistic, or organizational changes might have made this report's overall message more clear to the reader?

4. What additional actions could the Office of Inspector General have taken on the issues discussed in this report which would have been helpful?

Please include your name and telephone number so that we may contact you should we have any questions about your comments.

Name

Date

Telephone

Organization

When you have completed this form, you may telefax it to the Office of Inspector General at (202) 586-0948, or you may mail it to:

\author{
Office of Inspector General (IG-1) \\ Department of Energy \\ Washington, D.C. 20585 \\ ATTN: Customer Relations
}

If you wish to discuss this report or your comments with a staff member of the Office of Inspector General, please contact Wilma Slaughter (202) 586-1924. 